BOGDAN WALCZAK

Akademia im. Jakuba z Paradyża w Gorzowie Wielkopolskim

\title{
Dorota Kozaryn, Agnieszka Szczaus, Uwagi o języku w dawnych tekstach uizyt- kowych. Wydawnictwo Grafform, Szczecin 2017, ss. 80
}

Praca Doroty Kozaryn i Agnieszki Szczaus wypełnia wyraźną lukę w naukowej literaturze językoznawczej na temat tekstów dawnych. Przede wszystkim trzeba stwierdzić, że teksty użytkowe cieszą się umiarkowanym (by to określić możliwie delikatnie) zainteresowaniem badaczy - historyków języka. Wolno sądzić, że źródło tego umiarkowanego zainteresowania tkwi w tym, że polska historia języka jest wciąż jeszcze zdominowana przez model (moim zdaniem pod względem metodologicznym osadzony w paradygmacie pozytywistycznym ${ }^{1}$ ) stworzony przez Zenona Klemensiewicza, autora jedynej rozbudowanej syntezy (kompendium) historycznojęzykowej (Klemensiewicz 1961-1972). W modelu Klemensiewiczowskim decydująca rola źródłowo-materiałowa przypada tekstom artystycznym. Sam Z. Klemensiewicz mocno to podkreślał w programowym artykule Zatożenia i zagadnienia historii języka polskiego (Klemensiewicz 1956). Pisał tam: „W obrębie języka ogólnego zajmiemy się przede wszystkim, głównie językiem literackim. Dlaczego ? Po pierwsze, jest to odmiana języka jedynie dostępna badaniu skierowanemu w przeszłość" (Klemensiewicz 1956: 101). To stwierdzenie Z. Klemensiewicza należy rozumieć następująco: inne odmiany językowe albo są udokumentowane (w sensie filologicznym) fragmentarycznie (tak co do zakresu, jak i co do chronologii), albo są udokumentowane nie wprost, pośrednio, tzn. o ich kształcie trzeba wnioskować ze świadectw dostępnych filologicznie. $\mathrm{W}$ dalszym ciągu swojego wywodu podkreśla Z. Klemensiewicz historycznojęzykową rolę tekstów artystycznych: „W zakresie języka literackiego najwięcej uwagi przyciąga ku sobie językowe tworzywo literatury pięknej. Dlaczego ? Ponieważ daje ono pełnię języka jako środka komunikacji pełni życia człowieka myślącego, czującego, chcącego i działającego" (Klemensiewicz 1956: 102). Doskonałą realizacją tego modelu jest wielka synteza Klemensiewiczowska Historia języka polskiego, o której była już mowa wyżej. Przesłanie zarówno tej syntezy (podkreślmy jeszcze raz: jedynej syntezy historycznojęzykowej²), jak i artykułu programowego z roku 1956 (też już była o nim mowa wyżej) jest jasne: historyk

\footnotetext{
1 Innego zdania jest Stanisław Dubisz (2010) czy Andrzej Maria Lewicki (2001).

2 Opracowanie Jana Mazura (1993) jest adaptacją wątków historycznojęzykowych dla czytelnika - obcokrajowca i właściwie przynależy do glottodydaktyki polonistycznej, moje opracowanie, w gwarze studenckiej zwane nieraz „małym Klemensiewiczem” (Walczak 1995) jest tylko próbą (nie mnie rozstrzygać o tym, czy
} 
języka winien się głównie zajmować językiem artystycznym - ze względu na jego rolę kulturotwórczą i ze względu na to, że teksty artystyczne stanowią główną podstawę źródłowo-materiałową dla historyka języka polskiego.

W tym kontekście teksty użytkowe schodzą na drugi plan. Zyskują one wprawdzie na znaczeniu w obrębie innego, nieklemensiewiczowskiego modelu historii języka. Zapowiedział ten model Antoni Furdal w 1966 roku (Furdal 1966). Według A. Furdala historia języka winna obejmować ewolucję wszystkich stylów językowych. Dla tak pojmowanej historii języka powstał Wybór tekstów do historii języka polskiego autorstwa Stanisława Borawskiego i Antoniego Furdala z 1980 roku (Borawski, Furdal 1980). Zasadniczo w tym nurcie (metodologicznie komunikatywno-genologicznym) sytuuje się też ostatni, najobszerniejszy (583 teksty!), dwutomowy Wybór tekstów z dziejów języka polskiego (Cybulski 2015). Natomiast syntezy (kompendium historycznojęzykowego), opracowanej z tego stanowiska jeszcze nie ma (tzn. prawdopodobnie już istnieje, przygotowana z inicjatywy Stanisława Borawskiego, zespołowa (łódzko-zielonogórska, jak i najnowszy Wybór) synteza komunikacyjno-genologiczna historii języka polskiego, ale jeszcze jej nie ma na rynku księgarskim, w postaci dostępnej dla każdego książki).

Uprzedzając niejako tę syntezę (w której teksty użytkowe najrozmaitszego rodzaju znajdą zapewne poczesne miejsce jako podstawa źródłowo-materiałowa prezentowanych analiz), szczecińskie historyczki języka polskiego, Dorota Kozaryn i Agnieszka Szczaus, przedstawiają pracę o uwagach językowych w dawnych tekstach użytkowych (Kronice wszystkiego świata Marcina Bielskiego z 1564 roku i w dwu osiemnastowiecznych encyklopediach, autorstwa Wojciecha Bystrzonowskiego i Benedykta Chmielowskiego (Bystrzonowski 1743; Chmielowski 1745-1746)). Z tych tekstów większego zainteresowania (od strony językoznawczej głównie za sprawą Haliny Rybickiej (1974a; 1974b)) doczekała się tylko Akademija wszelkiej scyjencyi petna Benedykta Chmielowskiego. Literatury lingwistycznej o Kronice M. Bielskiego w zasadzie nie ma w ogóle, o dziele W. Bystrzonowskiego, poza Stanisławem Dubiszem (dwa zarysy biobibliograficzne (Dubisz 1978; 2007)) pisze tylko Agnieszka Szczaus, autorka monograficznego opracowania Informacyi matematycznej (Szczaus 2013) .

Praca szczecińskich autorek to książka merytorycznie zasadna, w zamierzonym zakresie wyczerpująca (autorki, zwłaszcza Dorota Kozaryn w odniesieniu do Kroniki Bielskiego, wyzyskała chyba w komplecie, przynajmniej gdy chodzi o typy i rodzaje, materiał wypowiedzi metajęzykowych w uwzględnionych dziełach) i doskonale przygotowana. Szczególnie zwraca uwagę (bo to już dziś, niestety, niepowszechne) znakomite przygotowanie językowe i pisowniowe.

Wysokiego stopnia filologicznej akrybii dowodzi choćby następujący komentarz do Kroniki M. Bielskiego: „Użyty przez Bielskiego na oznaczenie znaku alfabetu hebrajskiego leksem buksztab lub buksztaba (dane językowe nie pozwalają rozstrzygnąć, czy rzeczownik występował w rodzaju żeńskim, czy też męskim) [...]" (s. 20). Istotnie, u M. Bielskiego jest forma liczby mnogiej buksztaby, implikująca singularis buksztab lub buksztaba. Autorka (Dorota Kozaryn) uznała za konieczne dać wyraz tej dwojakiej możliwości, choć

udaną) przeróbki z kompendium Klemensiewicza na podręcznik do (okrojonej w programach studiów większości uniwersytetów i akademii) historii języka polskiego.

3 A. Szczaus opracowała leksykę drugiego wydania encyklopedii W. Bystrzonowskiego. 
i słowniki (na przykład dodany do antologii Witolda Taszyckiego (Taszycki 1969: 241)4), i inne przykłady użycia wskazują raczej na rodzaj męski. Można tu (za wspomnianą wyżej antologią (zmieniając transliterację W. Taszyckiego na własną transkrypcję) przywołać z Dworzanina Łukasza Górnickiego: „Aż wdy kiedy Bulgarowie, pożyczywszy buksztabów od Greków i przyczyniwszy ich nieco, a drugie przedziaławszy [mowa tu o genezie cyrylicy ${ }^{5}$ - B.W.], poczęli pisać jako tako, jednak przedsię pilnością swoją przyszli k temu za czasem, iż wiele pisma Bożego z łacińskiego i z greckiego na swój język przełożyli" (Taszycki 1969: 65)). Dopełniacz liczby mnogiej buksztabow zdaje się tu implikować formę liczby pojedynczej buksztab. Zdaje się - ale bezwzględnej pewności jednak nie ma (i stąd komentarz autorki dowodzi wysokiego stopnia filologicznej akrybii), gdyż wprawdzie genetywne formy typu boginiów, komisyjów, myszów, pieśniów, trosków, wsiów, zbrodniów itp. objawiły się na szerszą skalę dopiero w czasach stanisławowskich i na początku XIX wieku, sporadycznie występowały one jednak już w najdawniejszej polszczyźnie (filologicznie są zaświadczone od XVI wieku). Krótko mówiąc - żeńskiego rodzaju forma buksztaba nie jest wykluczona.

Książkę Doroty Kozaryn i Agnieszki Szczaus można polecić przede wszystkim historykom języka polskiego, ale także wszystkim zainteresowanym rozwojem polskiej refleksji o świecie, w szczególności pierwocinami polskiej literatury o charakterze encyklopedycznym.

\section{Bibliografia}

Borawski S., Furdal A., 1980, Wybór tekstów do historii języka polskiego, Warszawa.

Bystrzonowski W., 1743, Informacyja matematyczna rozumienie ciekawego Polaka świat caly, niebo, $i$ ziemię, $i$ co na nich jest $w$ trudnych kwestyjach i praktyce jemuz ułatwiajaca, Lublin.

Chmielowski B., 1745-1746, Nowe Ateny, albo Akademija wszelkiej scyjencyi petna, na różne tytuły jak na classes podzielona, madrym dla memoryjału, idyjotom dla nauki, politykom dla praktyki, melancholikom dla rozrywki erygowana, Lwów.

Cybulski M. (red.), 2015, Wybór tekstów z dziejów języka polskiego, t. I-II, Łódź.

Dubisz S., 1978, Wojciech Bystrzonowski - rys bio- i bibliograficzny (Z dziejów retoryki i dydaktyki polskiej), „Prace Filologiczne” XXVIII, s. 333-340.

Dubisz S., 2007, Wojciech Bystrzonowski - encyklopedysta i stylista, w: S. Dubisz, Język - historia - kultura (wyklady, studia, szkice), t. 2, Warszawa, s. 284-291.

Dubisz S., 2010, Historia języka polskiego - „wczoraj, dziś i jutro”, „LingVaria” 5, nr 2 (10), s. $45-57$.

Furdal A., 1966, Przedmiot i zakres historii języka polskiego, w: Studia językoznawcze poświęcone profesorowi doktorowi Stanisławowi Rospondowi, Wrocław-Warszawa-Kraków, s. 115-122.

Klemensiewicz Z., 1956, Zatożenia i zagadnienia historii języka polskiego, „Pamiętnik Literacki” XLIII, zesz. 3, s. 86-132.

Klemensiewicz Z., 1961-1972, Historia języka polskiego, cz. I-III, Warszawa.

Lewicki A.M., 2001, Językoznawstwo polskie w XX wieku, w: Wspótczesny język polski, red. J. Bartmiński, Lublin, s. 619-656.

\footnotetext{
4 Słownik zawiera hasło: bukstab, buksztab 'litera, czcionka'.

5 Zob. na ten temat: Walczak 1992.
} 
Mazur J., 1993, Geschichte der polnischen Sprache, Frankfurt am Main-Berlin-Bern-NewYork-Paris-Wien.

Rybicka H., 1974a, Nieznany rozdział o języku w „Nowych Atenach” Benedykta Chmielowskiego, „Prace Filologiczne” XXV, s. 529-535.

Rybicka H., 1974b, „,Nowe Ateny” Benedykta Chmielowskiego. Metoda, styl, język, Warszawa.

Szczaus A., 2013, Leksyka specjalistyczna w ,Informacyji matematycznej” Wojciecha Bystrzonowskiego z 1749 roku na tle polszczyzny XVIII wieku, Szczecin.

Taszycki W., 1969, Wybór tekstów staropolskich XVI-XVIII wieku, wyd. III, Warszawa.

Walczak B., 1992, Pierwszy polski wstęp do filologii słowiańskiej, w: XVII Konferencja Młodych Językoznawców: Język. Teoria - Dydaktyka, red. J. Brzeziński i P. Suder, Zielona Góra, s. 123-132.

Walczak B., 1995, Zarys dziejów języka polskiego, Poznań. 